\title{
STUDENTS' LEARNING OUTCOMES OF BLENDED LEARNING IMPLEMENTATION IN WRITING LESSON
}

\author{
Ayuni Madarina Abdul Rahman, Mohd Nazri Latiff Azmi \\ Faculty of Language and Communication \\ Universiti Sultan Zainal Abidin, 21030 Kuala Nerus, Terengganu, Malaysia \\ E-mail: ayunie858@gmail.com
}

Received: 02 November 2020

Accepted: 01 December 2020

\begin{abstract}
Writing requires specific skills in brainstorming, organizing, editing, and proofreading. There are varieties of research conducted in finding which approach is the most impactful to teach writing and one of the approaches emphasized is blended learning, widely acceptable in education field. Nevertheless, its effectiveness on writing is still questionable and the effort to integrate blended learning in teaching writing needs a thorough consideration. Therefore, the purpose of the study is to researcrh the adequacy of blended learning approach on students' writing performance. Employing an explanatory research type, an experimental research design was applied. A mixed-method method was executed to collect, analyse and interpret data. For quantitative, a quasi-experimental design was carried out to 60 respondents who were selected through purposive samplings and distributed to control and experimental groups. The study used pretest and posttest for both groups. The result shows that there is no significant difference of blended learning and students' writing performance between the experimental group and control group in the pretest and posttest. Overall, the study shows that both instructions have place in writing. Hence, educators have to become eclectic practitioners who are able to apply suitable approach that can contribute to the growth of teaching and learning writing.
\end{abstract}

Keywords: blended learning, writing, learning outcomes, teacher-centred learning.

\section{Introduction}

There are various issues highlighted in teaching writing in an English classroom as second language that somehow affecting overall students' language performance. Students were unable to acquire writing specific skills such as brainstorming, organizing, editing, and proofreading. Therefore, there are various researches conducted in finding which approach is the most impactful to teach writing.

In the era of modernization, technology has really brought positive impacts specifically to the educational world. Thus, many researches have discussed educators' and students' experiences, perceptions using technology in teaching and learning. The research proposed to conduct lessons using both traditional and online learning instructions will contribute to more powerful achievement.

According to Bowyer (2017), blended learning is the mixture of online and face to face learning, also known as hybrid learning or flipped classroom in some literatures. In further 
Students' Learning Outcomes of Blended Learning Implementation in Writing Lesson, Ayuni Madarina Abdul Rahman, Mohd Nazri Latiff Azmi

elaboration, Boelens, et.al (2015) defines blended learning as a situation that occurs in instructional context that is characterized by a cautious combination of online and classroom-based involvements to provide and initiate learning.

Blended learning is believed to be one of the tools that is able to improve students' understanding in learning second language. The combination of offline and online activities is expected to give better outcome than the traditional face-to-face activities. In comparison, traditional way of teaching occurs when educators solely give lecture whilst students enjoy note taking and one-way interaction learning (Banditvilai, 2011).

Thus, this study would like to see the significant difference of blended learning approach and students' writing performance between the experimental and control group in the pretest and posttest.

\section{Literature Review}

Writing is a necessary skill in mastering English language that is important not merely for education purpose but also for any career fields after graduation (Thirusanku \& Yunus, 2014). Writing is considered one of the four important and critical language skills for all students in all academic levels (Ahmadpour \& Khaasteh, 2017). It is also more significant for second language $(\mathrm{SL})$ and foreign language $(\mathrm{FL})$ students since they have to write in English language other than in their native languages (Challob, Bakar, Latif, 2016).

Novariana, et.al, (2018) has investigated the internal and external problems of writing. The internal problems are: 1) low motivations in learning English, 2) difficulty to choose the appropriate words in writing, 2) lack of vocabulary, 3) difficulty to arrange words in the appropriate order, 4) difficulty to spell the words, 5) difficulty to write the sentences in appropriate grammar, and 6) tendency to be passive learners in classroom activities. Meanwhile, the external problems are: 1 ) lack of practice, and 2) there is no feedback on their writing. The result indicates that students still have the identical difficulties as previous. Thus, e-journal is used to reduce the prolems where simultaneously has motivated students and improved their writing.

According to Annamalai, et.al, (2016), who conducted a study on a group of students who were required to do writing exercise and revision using Facebook medium, students tended to play a teacher like role when answering questions posted by their friends that showed their involvement in learning activities and increase their tech-savvy nature and this resulted in good learning behaviour since students had continuously built their confidence by engaging in online learning activities. Therefore, it is crucial for educators to find another solution or strategies to teach writing in ESL classroom for instance, blended learning as it is proven to be an effective approach (Annamalai, Tan \& Abdullah, 2016).

Milad (2017) conducted a study entitled Blended Learning Approach: Integrating Reading and Writing Research Skills to Improve Academic Writing. There were 31 students involved in this study that have taken Academic Writing course at the Faculty of Language Studies at one respective university. The study was conducted to examine students' performance in reading and writing skills in 15 weeks of duration. The teacher used WebQuests to employ blended learning approach in integrating reading and writing in students' learning. Students were connected to other students and the lecturer through online learning platform. The researcher has analysed the pre-test and post-test taken by students. The results yielded that the mean scores for the post-test was higher than the pre-test. Hence, it indicates that students' reading and writing research skills have improvement due to the involvement in blended learning approach using Web-Quests. 
Indriani (2017) has investigated the usage of Storybird.com in teaching English writing in her action research. There are 28 participants involved in this research from Writing Intensive Course class, English Department, Faculty of Education and Teacher Training. The research used non-test and test technique for data collection. The non-test are: (1) observation, it has been done to get the data of the students' behaviour in teaching and learning process, (2) documentation, it is the technique that is used to collect the data and information about the teaching and learning process. Test is used as one of the research instruments in pre cycle, cycle I and cycle II. As a result, students portrayed improvement in writing ability that illustrates the increment of the writing scores from 56.14 per cent to 84.28 per cent. The researcher concluded that students prefer to use blended learning medium in English leaning specifically with the usage of technology advancement and varied learning activities as for this study, Storybird.com website.

These highlighted issues of teaching and learning writing that may hinder students' writing performance that consequently affects their overall language performance. Thus, the research has been done in order to find out the most suitable approach to develop students' learning. One of the most effective ways is blended learning approach that is still widely used in educational field. Blended learning offers teaching and learning flexibility that enable to maximize students' anticipation in classroom. Besides that, blended learning offers tremendous materials available such as academic software, learning resources, e-notes, live streaming video, forum, blogs and others since students nowadays are keen to technology and more open to this kind of education as supported in study conducted by lke and Okechukwu (2015).

Students coming to class have a wide assortment of requirements, interests, previous information, and support, making this a challenge for instructors to separate these requirements while expanding all students' level of comprehension. Kubat (2018) discusses that school is moving far from the one-size-fits-all lesson design and educators' lesson plan must be advanced out of their usual range of comfort zone and push new ideas, keeping in mind the end goal to promote the learning of every last one of their students. Never again would educators be able to educate at the centre of the class and anticipate that everybody will fly on the grounds that the level of comprehension can be definitely not the same as class to class, table to table, seat to situate.

Nevertheless, there is still a scarce research pertaining to blended learning implementation in Communicative English 1 course particularly in Polytechnic Malaysia. In the light of the above, this study aims to study the impacts of blended learning on students' writing performance

\section{Research Method}

\subsection{Research Design}

The researchers used experimental research design to conduct this study. According to Fraenkel, Wallen and Hyun (2012), experimental research is unique in two crucial aspects. First, it is the only type of research that directly attempts to influence a particular variable. Second, when properly applied, it is the best type for testing hypothesis about cause-andeffect relationships.

For this study, the researchers used quasi-experimental and focused to collect data from dependent variables of this study which was the result for writing performance before and after blended learning intervention for both groups. In addition, quasi-experimental is the 
Students' Learning Outcomes of Blended Learning Implementation in Writing Lesson, Ayuni Madarina Abdul Rahman, Mohd Nazri Latiff Azmi

manipulation of independent variable and the absence of randomization selection. It is generally used to establish causality (effect of independent variable on dependent variable) in situations where a researcher is not able to randomly assign the subjects to groups for various reason. Therefore, it is very crucial to use this approach in order to examine the outcomes of different learning approaches implementation.

\subsection{Research Approach}

Quantitative research approach is used in this study to collect the data in order to see the relationships among variables. Harwell (2011) mentions that the key features of quantitative study are the use of instruments such as tests or surveys to collect data, and reliance on probability theory to test statistical hypotheses that correspond to research questions of interest.

\subsection{Data Collection}

For quantitative data collection procedure, 60 respondents were placed in two different groups known as control group and experimental group for 12-week study. Students were given pre-test for the first week of the implementation to discard any initial difference in both experimental and control groups. Using a writing module and following a writing module schedule, students in treatment group went through experiments using different learning materials, tools under blended learning climate. Meanwhile, control group learned under teacher-centred approach. At the end of the study, in week 12, the respondents answered the post-test given.

\subsection{Data analysis}

For this study, IBM SPSS version 23 was used to conduct The Mann-Whitney $U$ test analysis to examine the significant difference between the experimental and control group. Firstly, the pre-test marks were analyzed from both groups to discard any initial difference in both experimental and control groups. Secondly, the data obtained from post-test were then analyzed using same medium to test for differences between two independent groups on a continuous measure.

\section{Results and Discussion}

The Mann-Whitney $U$ Test is used to test for differences between two independent groups on a continuous measure

\section{PRE TEST BETWEEN GROUPS}

Table 1: Pre Test Between Groups

Descriptive Statistics

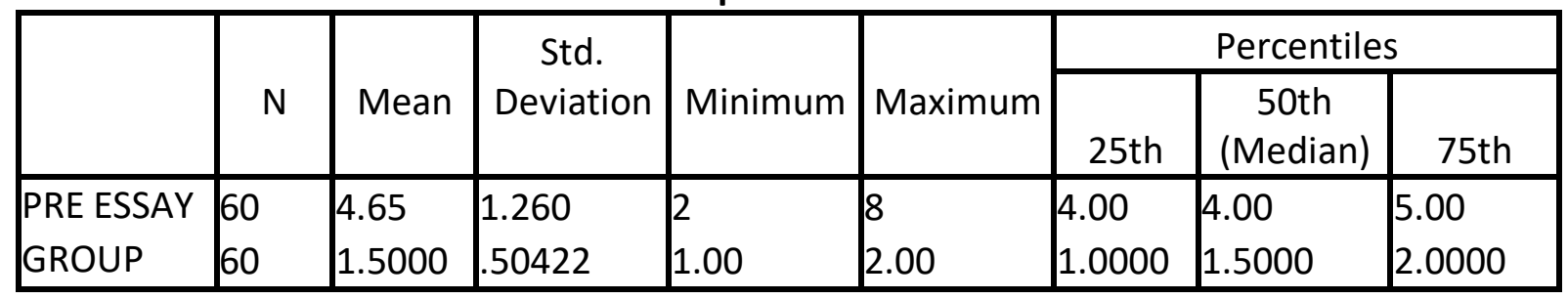


Table 2: Pre Test Between Groups

Ranks

\begin{tabular}{|l|l|l|l|l|}
\hline & \multicolumn{1}{|c|}{ GROUP } & \multicolumn{1}{c|}{$\mathrm{N}$} & Mean Rank & \multicolumn{1}{c|}{ Sum of Ranks } \\
\hline PRE ESSAY & CONTROL & 30 & 30.58 & 917.50 \\
& EXPERIMENTAL & 30 & 30.42 & 912.50 \\
& Total & 60 & & \\
\hline
\end{tabular}

Table 3: Pre Test Between Groups

Test Statistics ${ }^{\mathrm{a}}$

\begin{tabular}{|l|l|}
\hline & \multicolumn{1}{|c|}{ PRE ESSAY } \\
\hline Mann-Whitney U & 447.500 \\
Wilcoxon W & 912.500 \\
Z & -.038 \\
Asymp. Sig. (2-tailed) & .969 \\
\hline
\end{tabular}

a. Grouping Variable: GROUP

IBM SPSS version 23 was used to conduct Mann-Whitney $U$ test analysis to examine the significant difference between the experimental and control group. A Mann-Whitney test indicated that the pretest was significantly greater for control group as compared to experimental group $(\mathrm{Mdn}=4) U=447.5, p=.969$. There was no statistically significant difference.

POSTTEST BETWEEN GROUPS

Table 4: Posttest Between Groups

Descriptive Statistics

\begin{tabular}{|l|l|l|l|l|l|}
\hline & \multicolumn{1}{|c|}{$\mathrm{N}$} & \multicolumn{1}{|c|}{ Mean } & Std. Deviation & \multicolumn{1}{c|}{ Minimum } & \multicolumn{1}{c|}{ Maximum } \\
\hline POST Essay Marks & 60 & 5.65 & 1.325 & 4 & 8 \\
GROUP & 60 & 1.5000 & .50422 & 1.00 & 2.00 \\
\hline
\end{tabular}

Table 5 : Posttest Between Groups

Ranks

\begin{tabular}{|c|c|c|c|c|}
\hline & GROUP & $\mathrm{N}$ & Mean Rank & Sum of Ranks \\
\hline \multirow[t]{3}{*}{ POST Essay Marks } & CONTROL & 30 & 28.65 & 859.50 \\
\hline & EXPERIMENTAL & 30 & 32.35 & 970.50 \\
\hline & Total & 60 & & \\
\hline
\end{tabular}

Table 6: Posttest Between Groups

Test Statistics ${ }^{a}$

\begin{tabular}{|l|l|}
\hline & POST Essay Marks \\
\hline Mann-Whitney U & 394.500 \\
Wilcoxon W & 859.500 \\
Z & -.842 \\
Asymp. Sig. (2-tailed) & .400 \\
\hline
\end{tabular}

a. Grouping Variable: GROUP 
Mann-Whitney $U$ test analysis was conducted to investigate the significant difference between the experimental and control group in the pos-test. Mann-Whitney test shown that the posttest was significantly greater for experimental group as compared to control group, $U=394.5, p=.400>0.05$. There was no statistically significant difference. TherResult indicates that students who learned through the implementation of blended learning approach had obtained better results in their writing as compared to those who learned using traditional instruction. The implementation of writing module, writing strategies, online learning medium, interactive media, and face-to-face combination in a blended learning classroom has successfully affected students' writing performance.

In addition, educators might consider to mix traditional approach with technological advancement and online activities that can accelerate students' English learning specifically in writing skills. Nonetheless, the adopters of blended learning approach must consider the challenges and barriers (Mtebe \& Raisamo, 2014; Mtebe \& Raphael, 2013; Kisanga \& Ireson, 2015) that might be encountered to avoid any unnecessary incidents during the implementation.

\section{Conclusion}

There are a few limitations in conducting this study hence the results obtained cannot be generalized to other course and other institution. Firstly, the sample of the study is only from semester one students who learned Communicative English 1 in one respective Polytechnic Malaysia out of total population of 34 polytechnics. Thus, the result of this study cannot be generalized to other institutions or courses.

Second, the instruments used for the study were limited to one writing test, questionnaires and interview. The purpose of this study is to see which learning approach has given better writing performance for students. Nonetheless, if given more time and would benefit the literature, this topic can also further investigate the difference in pretest, posttest and delayed writing tests for both approaches. The questions in the questionnaires only comprised the general concept on Accessibility, Interaction, Benefits and Impacts of intended learning approach and it could be more focused on the tools, strategies, techniques in each instruction nevertheless it's another venture that can be taken into consideration.

To sum up, blended learning is a promising pedagogical approach that combines online delivery of content and instruction with some element of student centred learning and offline learning. Blended learning may expand learning viability, fulfilment, and productivity which promotes students' access, adaptability and flexibility to higher levels of information and learning skills. In addition, it may facilitate increased enrolment and improved utilization of physical facilities by requiring less physical involvement than fully face-to-face conventional learning.

\section{References}

Ahmadpour, Z. \& Khaasteh, R. (2017). Writing Behaviors and Critical Thinking Styles: The Case of Blended Learning. Doi: 10.5782/2223-2621.2017.20.1.5.

Annamalai, N., Tan, K. E., and Abdullah, A. (2016). Teaching Presence in an Online Collaborative Learning Environment via Facebook. Pertanika Journal of Social Sciences \& Humanities. 24(1), 197-212.

Banditvilai, C. (2016). Enhancing students' language skills through blended learning. 
The Electronic Journal of e-Learning, 14 (3), 220-229. Retrieved from www.ejel.org/issue/download.html?idArticle $=508$.

Boelens, R., Van Laer, S., De Wever, B., \& Elen, J. (2015). Blended Learning In Adult Education: Towards A Definition of Blended Learning. Retrieved from https://biblio.ugent.be/publication/6905076.

Bowyer, J. (2017). Evaluating blended learning: Bringing the elements Together. Retrieved from http://www.cambridgeassessment.org.uk/Images/375446-evaluating-blendedlearning-bringing-the-elements-together.pdf.

Challob, A. I., Bakar, N. A., \& Latif, H. (2016). Collaborative Blended Learning Writing Environment: Effects on EFL Students' Writing Apprehension and Writing Performance. http://www.ccsenet.org/journal/index.php/elt/article/view/60035.

Fraenkel, J.R., Wallen, N. E., \& Hyun, H. (2012). How to Design and Evaluate Research in Education. Boston. McGraw Hill Publisher.

Harwell, R. (2011). The SAGE Handbook for Research in Education: Pursuing Ideas as the Keystone of Exemplary Inquiry. New York: SAGE Publications.

Ike, E., \& Okechukwu, I. B. (2015). Effective learning systems through blended teaching modules in adult secondary education systems in developing nations: need for partnership. Journal of Adult and Continuing Education, 21(1). Retrieved from http://journals.sagepub.com/doi/abs/10.7227/JACE.21.1.3.

Indriani, L. (2017). Using Storybird for Teaching Writing in Blended Learning Environment: Is It a Waste of Time? https://sinta.ristekbrin.go.id/authors/detail?page=2\&id= 6149789\&view=documentsgs.

Kisanga, D., \& Ireson G. (2015). Barriers and strategies on adoption of e-learning in Tanzanian higher learning institutions: Lessons for adopters. International Journal of Education and Development using Information and Communication Technology (IJEDICT), 11(2), 126-137. https://files.eric.ed.gov/fulltext/EJ1074165.pdf.

Kubat, U. (2018). Identifying the Individual Differences among Students during Learning and Teaching Process by Science Teachers. International Journal of Research in Educational and Science, (IJRES), 4(1), 30-38. doi:10.21890/ijres.369746.

Milad, M. (2017). Blended Learning Approach: Integrating Reading and Writing Research Skills to Improve Academic Writing. https://files.eric.ed.gov/fulltext/EJ1207987.pdf.

Mtebe, J. S. \& Raisamo, R. (2014). Investigating Perceived Barriers to the Use of Open Educational Resources in Higher Education in Tanzania. The international review of research in open and distributed learning (IRRODL), 15(2). http://www.irrodl.org/index.php/irrodl/article/view/1803.

Mtebe, J. S. \& Raphael, C. (2013). Students' experiences and challenges of blended learning at the University of Dar es Salaam, Tanzania. International Journal of Education and Development using Information and Communication Technology (IJEDICT), 9(3), 124136. https://files.eric.ed.gov/fulltext/EJ1071342.pdf.

Novariana, Sumardi and Tanjana. (2018). Senior High School Students' Problems In Writing: A Preliminary Study of Implementing Writing E-Journal as Self Assessment to Promote Students' Writing Skill. Retrieved from https://jurnal.unimus.ac.id/index.php/ELLIC/article/view/3540

Thirusanku, J. \& Yunus. M. M. (2014). Status of English in Malaysia. Canadian Center of Science and Education, 10 (14), 254-260. Retrieved from http://www.ccsenet.org/ journal/index.php/ass/article/viewFile/37998/21197 